\title{
Balkanologie
}

Balkanologie Revue d'études pluridisciplinaires

Vol. XI, $n^{\circ} 1-2$ | 2008

Volume XI Numéro 1-2

\section{The Continuing Presence of the Extreme Right in Post-Milošević Serbia}

\section{Barbara N. Wiesinger}

\section{(2) OpenEdition \\ 1 Journals}

\section{Electronic version}

URL: http://journals.openedition.org/balkanologie/1363

DOI: 10.4000/balkanologie.1363

ISSN: 1965-0582

\section{Publisher}

Association française d'études sur les Balkans (Afebalk)

\section{Electronic reference}

Barbara N. Wiesinger, «The Continuing Presence of the Extreme Right in Post-Milošević Serbia », Balkanologie [Online], Vol. XI, n 1-2 | 2008, Online since 31 December 2008, connection on 17 December 2020. URL : http://journals.openedition.org/balkanologie/1363 ; DOI : https://doi.org/ 10.4000/balkanologie.1363

This text was automatically generated on 17 December 2020 .

(c) Tous droits réservés 


\title{
The Continuing Presence of the Extreme Right in Post-Milošević Serbia
}

\author{
Barbara N. Wiesinger
}

\section{Introduction}

1 This paper aims at surveying the extreme right scene in present-day Serbia. Its focus is on informal associations which represent the prototypical organizational form of the contemporary extreme right ${ }^{1}$ rather than on political parties. ${ }^{2}$ So far, such looselystructured groups have rarely been studied ${ }^{3}$, presumably because their societal impact seems hard to assess. ${ }^{4}$ The case of Serbia however, where they have flourished especially since the ousting of Slobodan Milošević, demonstrates that informal extreme right groups and networks, while they may not have realistic chances of usurping political power, can considerably limit the security and civil freedoms of other citizens. ${ }^{5}$ Over the past few years, Serbian extreme right activists have abused public space and the civil rights they deny others to spread their ideology of hatred and intimidate or even attack perceived enemies. ${ }^{6}$ The climate of insecurity and fear created by such mostly unsanctioned offences poses a threat to the strengthening of civil society and the success of democratic reform in Serbia which should not be underestimated.

Before I go on to discuss the programme and activities of Serbia's most visible extreme right groups in more detail, it might be useful to define the term "right-wing extremism". The most inclusive (and therefore also contentious) definition was suggested by the British historian Roger Griffin, who sees contemporary right-wing extremism as a form of fascism, which he defines as “(...) a political ideology whose mythic core in its various permutations is a palingenetic form of populist ultranationalism “8. Other scholars have proposed to include a second characteristic - a fundamental opposition to democratic values, institutions and processes - into the definition of right-wing extremism. ${ }^{9}$ Obviously, such minimum definitions are the 
result of idealizing abstraction and do not embrace all possible aspects of the phenomenon being investigated ${ }^{10}$. However, they seem useful in that they avoid the problems associated with definitions which enumerate various elements of right-wing extremism $^{11}$, for example, that it is not clear if the ideology of a given party or association has to demonstrate all, most, many, a few or maybe only one of those characteristics in order to be classified as extreme right.

In this paper, I classify such groups as extreme right (a) whose ultra-nationalist ideology emphasizes populism and the idea of renewal or rebirth culminating in the creation of a new social order (Griffin's definition)and (b) whose "political culture stands against the fundamentals of the democratic system “" ${ }^{12}$.

\section{Extreme right associations in contemporary Serbia}

Since 2001, the Serbian extreme right, which emerged during the 1990s, has gained considerable public visibility. ${ }^{13}$ Arguably, its flourishing is connected to Serbia's perennial political and economic instability as well as to the accompanying crisis in value orientation and social norms. ${ }^{14}$ The Serbian extreme right scene is a loosely-knit network of informal groups which can be (and sees itself as) divided into two camps. The Christian right, whose ideology is characterized by clerical nationalism, political conservatism, and xenophobia, has forged links with the Serbian Orthodox Church (Srpska Pravoslavna Crkva, SPC) as well as with the political establishment ${ }^{15}$. The most prominent groups in this camp are the Srpski Sabor Dveri (Serbian Assembly Doorway ${ }^{16}$ ) and the Otačastveni Pokret Obraz (Fatherland Movement Dignity). Students' associations such as Sveti Justin Filozof ${ }^{17}$ (Saint Justin the Philosopher), which originated at Belgrade University's Faculty of Philosophy, or Nomokanon ${ }^{18}$, anassociation of law students, and the group Vitez (Knight), which is based at Belgrade's medical school, also belong to the Christian right. ${ }^{19}$

5 The racist extreme right, which is well-connected to international neo-Nazist and white supremacist networks, consists of groups such as Krv $i$ Čast (Blood and Honour), Nacionalni stroj (National Formation)and Rasonalisti ${ }^{20} .{ }^{21} \mathrm{Just}$ like the Christian right, these groups stress xenophobia, authoritarianism and the need for a fundamental renaissance of the nation. What distinguishes them is their insistence on the centrality of "race", while Orthodox religion is relegated to the background. The racist extreme right seems to have less activists than the Christian right. Since it has repeatedly and aggressively encroached on public space, however, it should not be lightly dismissed as marginal.

Currently, the Serbian extreme right seems to concentrate on spreading its worldview through publications and events such as public discussions, concerts, demonstrations etc. Its most important platform is the internet, which activists and sympathizers use to communicate with each other, announce events, and circulate propaganda material. ${ }^{22}$ Many extreme right groups also publish magazines and books; one even hosts a TV programme. ${ }^{23}$ 


\section{The Christian right: Srpski Sabor Dveri and Otačastveni Pokret Obraz}

7 The Srpski Sabor Dveri originated in 1999 when a group of students of Serbian philology at Belgrade University started publishing the magazine Dveri Srpske. ${ }^{24}$ Today, the Srpski SaborDveri has chapters in more than 20 Serbian towns. Dveri regularly organize wellattended public lectures and meetings in Belgrade, other Serbian towns and abroad. ${ }^{25}$ Together with Vitez, an association of Orthodox physicians, Dveri campaign against abortion and for higher birth-rates to strengthen the Serbian nation(Pokret za život) Movement for Life) ${ }^{26}$. Dveri are affiliated with the Association of Serbian Youth (Sabor Srpske Omladine). ${ }^{27}$ They also initiated the Srpska Mreža (Serbian network), a network of Christian Right groups. ${ }^{28}$

8 Dveri's programme is based on svetosavlje, i.e. a combination of Serbian Orthodox piety and extremely nationalist attitudes. ${ }^{29}$ The prominent place Dveri accord to svetosavlje links their programme to early $20^{\text {th }}$ century Serbian Orthodox thinkers such as Bishop Nikolaj Velimirović, who is controversial because of his anti-Semitic opinions ${ }^{30}$. In a speech entitled "The Nationalism of St. Sava" (1935), Velimirović portrayed the medieval saint as the creator of the SPC and of the Serbian nation, thereby postulating an indissoluble bond between religious and national sentiments. ${ }^{31}$ In accordance with this interpretation of Saint Sava's heritage, Dveri propagate the close cooperation of state and church, which they see symbolized in the two-headed eagle of the Serbian coat of arms and personified in Saint Sava and his brother Saint Stefan Prvovenčani. ${ }^{32}$ Consequently, Dveri demand substantial changes in the political system which would give more power to professional associations and "crkveno-narodni sabori", councils of (arbitrarily chosen) "representatives of the people" and the SPC. ${ }^{33}$ Dveri also promote the restauration of the monarchy. ${ }^{34}$

9 A conviction that there is a special bond between god and the Serbian nation lies at the centre of Dveri's worldview. Supposedly, Saint Sava forged a covenant (zavet) with god, which was later confirmed by Car Lazar when he opted for a "heavenly kingdom" (carsko nebesko) on the eve of the Battle of Kosovo Polje (1389). By organizing the 1804 Serbian uprising against the Ottomans, Karađorde renewed this covenant. The Serbian nation is obliged to eternally bear witness to the covenant by respecting the nation's spiritual and moral values and by defending its ethnic territory. ${ }^{35}$ This includes the repression of everything deemed "abnormal": "For Serbs, homosexuality and other forms of deviant behaviour, abortion or sectarianism [i.e. membership in non-traditional religious groups or participation in their activities, BNW] cannot be normal phenomena and we will fight against them by peaceful means." 36

10 In their programme and other publications, Dveri stress a nationalized religiousness, secular national issues and the need for a comprehensive renewal (obnova) of the nation which alone would make Serbia once again "strong and healthy". ${ }^{37}$ Their ethnopluralism ${ }^{38}$, as well as their homophobia and non-acceptance of alternative faith groups, points to the fact that their proclaimed tolerance ${ }^{39}$ is rather limited. Also, Dveri express a deep-seated mistrust not only of the current political elite, but more generally of liberal democracy, which they aim to replace with a hierarchical society governed by pseudo-democratic institutions (the crkveno-narodni sabori) and a king. In Dveri's utopia religious, political and personal freedom would be restricted in case of its incompatibility with the "spiritual and moral values" of the Serbian nation. Following 
the definition given in the introduction, Dveri could therefore be classified as belonging to the extreme right. Importantly, however, Dveri is the only organization discussed in this article which admits the importance of human rights ${ }^{40}$ and explicitly limits its struggle for a national renaissance to peaceful means.

The Otačastveni Pokret Obraz is a more radical Christian right organization, which was set up in the mid-1990s when a group of Belgrade students began publishing the magazine Obraz. ${ }^{41}$ Today, the association allegedly has several thousand activists in Serbia, Montenegro, and the Republika Srpska. ${ }^{42}$ Obraz,led until 2001 by the late Nebojša M. Krstić ${ }^{43}$, became notorious when a number of its members participated in the assault on the 2001 lesbian and gay pride parade in Belgrade ${ }^{44}$. Over the years, various racist, especially anti-Semitic, graffiti were attributed to Obraz; however, such accusations were never proven. ${ }^{45}$

Similarly to Dveri, Obraz sees orthodox piety and an exaggerated patriotism as the foundations of the Serbian nation and frequently refers to Nikolaj Velimirović as its chosen spiritual and moral authority. ${ }^{46}$ Using the words of epic poetry, the association represents its activities as a struggle for the "honourable cross" and "golden freedom". ${ }^{47} \mathrm{Obraz}$ portrays itselfas the furtherer of the Serbian nation's resurrection on the basis of svetosavlje: "Obraz is the only movement for a school with faith, politics with honour, a patriotic army and a state with God's blessing." ${ }^{48} \mathrm{Obraz}$ 's central goal is the establishment of a strong and wealthy nation-state which would be able to defend itself against its many perceived enemies. ${ }^{49}$ In order to achieve this, liberal democracy, which Obraz calls a "judeo-masonic" tool of oppression, must be replaced by a corporative state led by patriotic and pious statesmen. ${ }^{50}$ In Obraz's ideal society, "offences" such as homosexual orientation or a non-Orthodox creed would be punishable. ${ }^{51}$

What distinguishes Obraz from the more moderate Dveri is Obraz's openly proclaimed hatred for non-Serbs, especially for Albanians, Muslims and Croats, their fervent antiSemitism and their repeated threats to resort to violence in order to realize their aims. ${ }^{52}$ It comes as no surprise that Obraz denies any Serbian responsibility for the Yugoslav wars of secession ${ }^{53}$ and celebrates Radovan Karadžić and Ratko Mladić as Serbian heroes $^{54}$. In 2002, for example, the organisation launched a campaign in support of Radovan Karadžić under the heading "Every Serb is Radovan" "Svaki je Srbin Radovan"). ${ }^{55}$ Furthermore, Obraz threatensthat Serbia will use force to regain hold of Croatia, Bosnia-Herzegovina and Kosovo, which it defines as "territories of the Serbian Fatherland". ${ }^{66}$

Even such a short survey of Obraz's programme shows that the organization fulfills the criteria for being classified as extreme right. ${ }^{57}$ Firstly, Obraz promotes an aggressive nationalism with strong clericalist elements. Secondly, it claims that a profound renewal is necessary for the Serbian nation to overcome its present wretched and decadent state. Thirdly, Obraz rejects liberal democracy and the humanistic values it is based on.Fourthly, Obraz endorses the use of violence against opponents. ${ }^{58}$

\section{Krv i Čast and Nacionalni stroj}

15 The association $\mathrm{Krv}$ i čast (Blood and Honour)was founded in 1995 as a member of the international, UK-based Blood and Honour neo-Nazi network ${ }^{59.60} \mathrm{Combat} 18^{61}$, an organization which $\mathrm{Krv} i$ čast describes as its activist branch, was set up in $2003 .{ }^{62} \mathrm{Krv} i$ čast boasts chapters in Belgrade, Novi Sad, Nǐ̌, Apatin and Jagodina. It publishes four 
magazines, organizes concerts, participates in neo-Nazi meetings abroad, regularly celebrates Hitler's birthday etc. ${ }^{63} \mathrm{Krv} i$ čast promotes "leaderless resistance", a strategy which emphasizes individual and small group activism. There is no formal membership, making it impossible to say how many activists the organization has. ${ }^{64}$

$\mathrm{Krv} i$ čast is affiliated with Nacionalni stroj (National formation), another informal white supremacist and ultra-nationalist group. ${ }^{65}$ The $\mathrm{Krv} i$ čast website features the programme and proclamations of Nacionalni stroj, reports on its activities and promotes its controversial leader Goran Davidović ${ }^{66}$. Nacionalni stroj's programme is very similar to that of Krv $i \check{c}$ ast, and as a member of the US-based white supremacist network Stormfront, Nacionalni stroj undoubtedly belongs to what could be termed the "racist international".

Over the past few years, activists of Krv $i$ čast and Nacionalni stroj may or may not have been involved in incidents such as the destruction of the Belgrade and Niš mosques in March 2004 (connected to clashes between Albanians and Serbs in Kosovo in the same month ${ }^{67}$ ), attacks on the pacifist group Žene $u$ crnom (Women in Black) in July 2005, and, more recently, an assault on Bosnian and Serbian peace activists in Niš (May 2007). In any case, these and other similar incidents are celebrated on Krv $i$ čast's website as laudable patriotic acts. ${ }^{68}$ In autumn 2007, Krv $i$ čast and Nacionalni stroj organized a nationalist rally in Novi Sad (the "March for Serbian Unity"), which was prohibited by the local authorities. Nevertheless, several dozen extreme right activists were able to gather in the city centre, which resulted in clashes with counter-protesters. ${ }^{69}$ Planning for similar marches to take place this year is already under way. ${ }^{70}$ The "activism" of Nacionalni stroj and Krv $i$ čast includesdiscriminatory graffiti on public and private property, which constitutes an offence under Serbian law as an incitement of ethnical, racial or religious hatred. ${ }^{71}$

$\mathrm{Krv}$ i čast can undoubtedly be classified as a neo-Nazist association. Not only do they openly admire National Socialism and venerate Adolf Hitler. Even more significantly, they believe that humanity is divided into unequal "races" of which the white "race" is allegedly the most highly evolved. In the modern world, however, the white "race" is in peril of extinction unless it overcomes the ills of multi-culturalism, decadence and democracy through a revolutionary struggle for its biological continuance and cultural rebirth..$^{72}$ This rebirth depends, inter alia, on higher birth-rates and a ban on abortion a view that Krv $i$ čast share with the Christian right groups Dveri and Obraz. ${ }^{73}$ According to Krv $i$ c $a s t$, the most dangerous enemies of the white "race" are the Jews ${ }^{74}$, who are held responsible for the current sorry state of Serbia ${ }^{75}$ and especially for the 1999 NATO bombardement ${ }^{76}$ (a claim also made by $0 b r a z^{77}$ ). The neighbouring nations, who are said to unjustly "occupy" the "Serbian" territories of Bosnia-Herzegovina, Montenegro, and Kosovo $^{78}$, are similarly disliked by Krvi čast activists.

The programme of Nacionalni stroj resembles that of Krv $i$ čast. Nacionalni stroj promotes the "preservation and rebirth of the healthy values of the Serbian nation as a constituent part of the white race". ${ }^{79}$ The associationdemands a centralized nation-state based on "national liberty, social rights and the racial-biological protection of the nation". According to Nacionalni stroj, "racial" and national consciousness have the potential to overcome the conflicting interests of different strata of society, resulting in the harmonious coexistence of the "organic national community". This community would be led by an authoritarian head of state, who would enjoy the support of a strong army and the national church, presumably the SPC. Only white people loyal to the Serbian nation 
would be entitled to full citizenship. Furthermore, the media would be controlled by the state, while homosexuality, pornography, abortion and non-traditional religious groups would be outlawed..$^{80}$

Krv i čast and Nacionalni stroj clearly deserve the label "extreme right". They promote an aggressive nationalism, based on the purported supremacy of the white "race". They claim to fight a revolutionary struggle for the renewal of the Serbian nation and the white "race" in general. Krv $i$ čast and Nacionalni stroj incite hatred against other nations, political opponents and religious, ethnic and sexual minorities. They despise the notion of equality, reject democracy, and, judging by their activism, endorse the use of violence to further their aims.

\section{Summary and outlook}

This paper surveyed the extreme right scene in contemporary Serbia and discussed four groups - Srpski Sabor Dveri, Otačastveni Pokret Obraz, Krv i čast and Nacionalni stroj in more detail. It showed that the programmes of these organizations are strikingly similar in that they focus on an exaggerated nationalism centred on the idea of national rebirth and a populist suspicion of democratic values, institutions and processes. The main difference seems to be that the Christian right groups yearn for a renewal of the nation through a return to "traditional values", among which Orthodox piety, hierarchical social relations and a rural way of life feature most prominently, while the racist right associations strive for a national renaissance based on the alleged supremacy of the white "race". In their call for authoritarian rule and a strong leader who would guarantee national unity by suppressing internal dissent while at the same time "defending" the nation's interests against its many perceived external enemies, all four groups are united. They also share a hatred of difference which expresses itself in the refusal to accept as legitimate opinions and lifestyles other than their own.

Necessarily, the descriptive survey presented in this article leaves many questions unanswered. What do individual activists and sympathizers believe, and how does that relate to the programmes formulated by extreme right groups and parties on the one hand, and the opinions of the non-extremist majority of Serbian citizens on the other? How widespread are extreme right ideas in contemporary Serbia? How can we evaluate Serbian right-wing extremism in its international context? To answer these questions, further and more detailed research is needed.

\section{BIBLIOGRAPHY}

Primary sources and online media reports are fully quoted in the footnotes.

Amnesty International (2001). Concerns in Europe, January to June 2001, Federal Republic of Yugoslavia/Serbia and Montenegro. Available from www.anmesty.org/library, accessed $14 / 11 / 2007$. 
Betz, Hans-Georg (2003). 'The Growing Threat of the Radical Right', in Peter H. Merkl and Leonard Weinberg (eds) Right-Wing Extremism in the Twenty-First Century. London/Portland, OR: Cass: 74-93.

Byford, Jovan (2002). 'Christian Right-Wing Organizations and the Spreading of Anti-Semitic Prejudice in Post-Milosevic Serbia: The Case of the Dignity Patriotic Movement',East European Jewish Affairs 32(2): 43-60.

Byford, Jovan (2003). 'Anti-Semitism and the Christian Right in post-Milošević Serbia: From conspiracy theory to hate crime', Internet Journal of Criminology (IJC). Available from www.internetjournalofcriminology.com, accessed 24/04/2008.

Byford, Jovan (2004a). From 'Traitor' to 'Saint': Serbian Bishop Nikolaj Velimirovic in Public Memory. Analysis of Current Trends in Antisemitism series (ACTA), No. 22, published by the Sassoon International Centre for the Study of Antisemitism, Hebrew University, Jerusalem.

Byford, Jovan (2004b). 'Canonisation of Bishop Nikolaj Velimirović and the legitimisation of religious anti-Semitism in contemporary Serbian society', East European Reports, 6 (3).

Byford, Jovan (2006a). ' 'Serbs never hated the Jews': the denial of anti-Semitism in contemporary Serbian Orthodox Christian culture', Patterns of Prejudice, 40(2): 159-180.

Byford, Jovan (2006b). ‘Distinguishing ‘Anti-Judaism' From ‘Anti-Semitism': Recent championing of the Serbian Bishop Nikolaj Velimirović', Religion, State and Society, 34(1): 7-31.

Đorđević, Mirko. Srpska konzervativna misao. Belgrade: HCHRS, 2003.

Eatwell, Roger (2003). 'Ten Theories of the Extreme Right', in Peter H. Merkl and Leonard Weinberg (eds) Right-Wing Extremism in the Twenty-First Century. London/Portland, OR: Cass: 47-73. Fromm, Rainer (2007). Rassistischer Hass im World Wide Web. Die weltweite Vernetzung von Neonazis im Internet. Available from www.bpb.de/themen/2BWYNR.html, accessed 21/01/2008. Griffin, Roger (2006). 'Fascism's new faces (and new facelessness) in the „post-fascist“ epoch', in Griffin Roger et al. (eds) Fascism Past and Present, West and East. An International Debate on Concepts and Cases in the Comparative Study of the Extreme Right. Stuttgart: ibidem: 29-67.

Hagtvet, Bernt (1994): 'Right-Wing Extremism in Europe', Journal of Peace Research, 31(3): 241-246. Ignazi, Piero (2002). 'The Extreme Right: Defining the Object and Assessing the Causes', in Martin Schain et al. (eds) Shadows over Europe. The Development and Impact of the Extreme Right in Western Europe. New York/Basingstoke: Palgrave Macmillan: 21-37.

Irvine, Jill A. (1995). 'Nationalism and the extreme right in the former Yugoslavia', in Luciano Cheles et al. (eds) The Far Right in Western and Eastern Europe. London/New York: Longman: 145-173.

Jaschke, Hans-Gerd (2006). Rechtsextremismus. Available from www.bpb.de/themen/ DU09IB.htm, accessed 21/01/2008.

Kowalsky, Wolfgang and Schröder, Wolfgang (1994). 'Einleitung. Rechtsextremismus - Begriff, Methode, Analyse', in Wolfgang Kowalsky and Wolfgang Schröder (eds) Rechtsextremismus. Einführung und Forschungsbilanz. Opladen: Westdeutscher Verlag: 7-20.

Maegerle, Anton (2007). Die Armee der weißen Rasse. Neonazis und andere Rechtsextremisten in Osteuropa. Available from www.bpb.de/themen/22I31T.html, accessed 21/01/2008.

Mudde, Cas (2005). 'Central and Eastern Europe', in Cas Mudde (ed) Racist Extremism in Central and Eastern Europe. London/New York: Routledge: 267-285. 
Nikolić, Zoran B. (2001). Vajmarska Srbija. Available from www.b92.net, accessed 16/01/2008.

Petrović Ivana and Nikola Lazić (2005). Klerikalna desnica pridobija srpsku omladinu. Available from http://www.razmena.org/sh/88/1/746/?tpl=94, accessed 25/04/2008.

Pribićević, Ognjen (1999). 'Changing Fortunes of the Serbian Radical Right', in Sabrina P. Ramet (ed) The Radical Right in Central and Eastern Europe since 1989. University Park: Pennsylvania State University Press: 193-211.

Ramet, Sabrina P. (1999): 'Defining the Radical Right: The Values and Behaviors of Organized Intolerance', in Sabrina P. Ramet (ed) The Radical Right in Central and Eastern Europe since 1989. University Park: Pennsylvania State University Press: 3-27.

Schenkel, Dominik (2007). Neonazis auf YouTube. Rechtsextreme Selbstdarstellung im „Weltnetz“. Available from www.bpb.de/themen/NOSAXQ.html, accessed 21/01/2008.

Stephen Roth Institute for the Study of Contemporary Anti-Semitism and Racism (2005): Republic of Serbia 2005 Annual Report. Available from www.tau.ac.il/Anti-Semitism/asw2005/serbia.htm, accessed 14/11/2007.

Williams, Christopher (1999). 'Problems of Transition and the Rise of the Radical Right', in Sabrina P. Ramet (ed) The Radical Right in Central and Eastern Europe since 1989. University Park: Pennsylvania State University Press: 29-47.

Tálos, Emmerich and Manoschek, Werner (2005). 'Aspekte der politischen Struktur des Austrofaschismus' in Emmerich Tálos and Wolfgang Neugebauer (eds) Austrofaschismus. PolitikÖkonomie - Kultur 1933-1938.Vienna: Lit: 124-160.

Zorica Kuburić (no date given). Crkve i verske zajednice u Srbiji i Crnoj Gori. Available from www.ff.ns.ac.yu/stara/elpub/susretkultura/40.pdf, accessed 28/04/2008.

\section{NOTES}

1. Griffin (Roger), "Fascism's new faces (and new facelessness) in the "post-fascist" epoch », in Griffin (Roger) et al., éds, Fascism Past and Present, West and East. An International Debate on Concepts and Cases in the Comparative Study of the Extreme Right. Stuttgart: ibidem, 2006, pp. 54-56; Eatwell, (Roger), "Ten Theories of the Extreme Right », in Merkl (Peter H. ), Weinberg (Leonard), éds, Right-Wing Extremism in the Twenty-First Century, London/Portland, OR, Cass, 2003, p.106.

2. Since the early 1990s, the Serbian Radical Party (SRS, Srpska Radikalna Stranka) has been the most important extreme right party in Serbia (cf. Irvine (Jill A.), « Nationalism and the extreme right in the former Yugoslavia ", in Cheles (Luciano) et al., éds., The Far Right in Western and Eastern Europe. London/New York: Longman, 1995, pp.145-173., Pribićević (Ognjen), « Changing Fortunes of the Serbian Radical Right ", in Ramet (Sabrina P.), éd., The Radical Right in Central and Eastern Europe since 1989. University Park, Pennsylvania State University Press, 1999, pp. 193-211., Thomas (Robert), Serbia under Milosevic : Politics in the 1990s, London, Hurst, 1999). Other extreme right parties include(d) the Serbian Saint Sava Party (Srpska Svetosavska Stranka) and Željko Ražnjatović-Arkan's Party of Serbian Unity (Stranka Srpskog Jedinstva), which joined the SRS in December 2007 (http://www.blic.co.yu, 23/12/2007, accessed 30/01/2008).

3. Mudde (Cas), "Central and Eastern Europe ", in Mudde (Cas), éd., Racist Extremism in Central and Eastern Europe. London/New York, Routledge, pp.269-271)

4. Eatwell (Roger), "Ten Theories of the Extreme Right», in Merkl (Peter H. ), Weinberg (Leonard), éds., Right-Wing Extremism in the Twenty-First Century. London/Portland, OR, Cass, 
2003, p.68. An exception is the work of British psychologist Jovan Byford, who has published on the Serbian Christian right ( Christian Right-Wing Organizations and the Spreading of AntiSemitic Prejudice in Post-Milosevic Serbia: The Case of the Dignity Patriotic Movement », East European Jewish Affairs, 32(2), 2002, pp.43-60; "Anti-Semitism and the Christian Right in postMilošević Serbia: From conspiracy theory to hate crime ", Internet Journal of Criminology (IJC), 2003) and more generally on the emergence of anti-Semitism in contemporary Serbia : "Serbs never hated the Jews: the denial of anti-Semitism in contemporary Serbian Orthodox Christian culture », Patterns of Prejudice, 40(2), 2006, pp.159-180; « Distinguishing 'Anti-Judaism' From 'AntiSemitism': Recent championing of the Serbian Bishop Nikolaj Velimirović ", Religion, State and Society, 34(1), 2006, pp.7-31.

5. To cite just two examples: In February 2008, members of Obraz prevented the opening of an exhibition featuring works by Kosovo Albanian artists (cf. «Obraz i policija u centru Beograda », 07/02/2008, http://www.b92.net/, accessed 27/04/2008, « Neophodna zabrana klerofašističkih organizacija ", 09/10/02/2008, http://www.danas.co.yu/, accessed 27/04/2008, "Sprečavanje šiptarske izložbe u Beogradu ", 07/02/2008, http://www.srb-obraz.org/, accessed 01/03/2008). A few days later, self-declared sympathizers of the same organization tried to prevent the promotion of a publication by contributors to the critical radio broadcast Peščanik ( Obraz na promociji knjige Peščanika", 12/02/2008, http://www.b92.net/, accessed 27/04/2008, «Obrazovci napali autore Peščanika», 13/02/2008, http://www.blic.co.yu/, accessed 27/04/2008).

6. Attacks on members of Serbia's Muslim, Romany and Jewish minorities proliferate (cf. AI 2001, Byford 2003:5f, Stephen Roth Institute 2005). Sexual minorities are also targeted by violent extremists, as the incidents in connection with the 2001 gay pride parade in Belgrade illustrate (cf. AI 2001, Nikolić 2001). Frequent threats against critical journalists and civil rights activists (cf. GSA: Policija ignoriše pretnje, 22/04/2008, Pretnje smrću predsedniku NDNV, 05/04/2007, both on http://www.b92.net/, accessed 26/04/2008) can often also be traced to origins in the extreme right scene.

7. For a comprehensive discussion pertaining especially to Central and Eastern Europe, cf. Ramet 1999.

8. Griffin (Roger), « Fascism's new faces (and new facelessness) in the „post-fascist" epoch », in Griffin (Roger) et al., éds, Fascism Past and Present, West and East. An International Debate on Concepts and Cases in the Comparative Study of the Extreme Right. Stuttgart: ibidem, 2006, p.41; Betz (Hans-Georg), « The Growing Threat of the Radical Right », in Merkl (Peter H. ), Weinberg (Leonard), éds., Right-Wing Extremism in the Twenty-First Century. London/Portland, OR, Cass, 2003, p.76; Ignazi, (Piero), « The Extreme Right: Defining the Object and Assessing the Cause », in Schain (Martin) et al., éds, Shadows over Europe. The Development and Impact of the Extreme Right in Western Europe. New York/Basingstoke, Palgrave Macmillan, pp.24-25)

9. Ignazi, (Piero), « The Extreme Right: Defining the Object and Assessing the Cause », in Schain (Martin) et al., éds, Shadows over Europe. The Development and Impact of the Extreme Right in Western Europe. New York/Basingstoke, Palgrave Macmillan, p.23 and 25-27; Jaschke (Hans-Gerd), Rechtsextremismus. Available from www.bpb.de/themen/DU09IB.htm, accessed 21/01/2008, p.2). For a critique of the emphasis on the anti-system properties of right-wing extremism in many definitions see Kowalsky (Wolfgang), Schröder (Wolfgang), « Einleitung. Rechtsextremismus Begriff, Methode, Analyse ", in Wolfgang Kowalsky and Wolfgang Schröder, éds, Rechtsextremismus. Einführung und Forschungsbilanz. Opladen, Westdeutscher Verlag, 1994, p.9.

10. Griffin (Roger), « Fascism's new faces (and new facelessness) in the „post-fascist" epoch », in Griffin (Roger) et al., éds, Fascism Past and Present, West and East. An International Debate on Concepts and Cases in the Comparative Study of the Extreme Right. Stuttgart: ibidem, 2006, p.37.

11. Hagtvet (Bernt), « Right-Wing Extremism in Europe », Journal of Peace Research, 31(3), 1994, p. 241. 
12. Ignazi, (Piero), "The Extreme Right: Defining the Object and Assessing the Cause ", in Schain (Martin) et al., éds, Shadows over Europe. The Development and Impact of the Extreme Right in Western Europe. New York/Basingstoke, Palgrave Macmillan, p.25.

13. Krv $i$ Čast was founded in 1995, the closely affiliated group Combat 18 in 2003 (http:// www.bhserbia.org/interview.htm, accessed 14/11/2007). The Otačastveni pokret Obraz was founded in 1998 (cf. http://www.srb-obraz.org/, Hronologija, accessed 01/03/2008; see also Stephen Roth Institute 2005, Nikolić 2001, AI 2001.) The Srpski Sabor Dveri - Nacionalna Organizacija Slobodnih Ljudi started with a student paper in 1999 (cf. http://www.stari.dverisrpske.com/, O Nama, accessed 15/11/2007).

14. Several important aspects of Serbian statehood - territory, form of government, constitution, and symbols - remained unresolved until rather recently. Political violence, which culminated in the 2003 assassination of Prime Minister Zoran Đinđić, also contributed to Serbia's instability. Roger Eatwell (2003:50-58) called explanations of the rise and success of right-wing extremism that focus on such structural aspects „demand-side theories“.

15. Byford (Jovan), "Christian Right-Wing Organizations and the Spreading of Anti-Semitic Prejudice in Post-Milosevic Serbia: The Case of the Dignity Patriotic Movement ", East European Jewish Affairs 32(2), 2002, pp.43-60., Petrović (Ivana), Lazić (Nikola), Klerikalna desnica pridobija srpsku omladinu, 2005. Available from http://www.razmena.org/sh/88/1/746/?tpl=94, accessed 25/04/2008)

16. This translation follows Byford 2003:6. Literally, dveri means doors. The term refers to the doors in the ikonostas, the partition in Orthodox churches which divides the sanctuary from the nave (cf. Kuburic:4).

17. The association promotes "national values" in institutions of higher education with the aim of introducing such contents into teaching and research as would "lead to the spiritual and cultural renewal" of the Serbian nation. http://www.svetijustin.cjb.net/, O nama, accessed 26/04/2008.

18. Cf. their site http://www.nomokanon.org.yu/.

19. These groups' classification as extreme right, however, would need to be based on a thorough analysis of their respective ideology and activities which this short survey cannot offer. 20. A pun on rasa/race and nacionalisti/nationalists. Cf. their site http://www.rasonalisti.net/.

21. All three associations were classified as neo-Nazist by the Serbian Interior Ministry. Cf. Prvi zvaničan spisak neonacista (10/12/2005), http://www.b92.net/, accessed 14/11/2007.

22. Internet forums and blogs are the most important means of communication for the extreme right. See for example Komentar-Srpski Internet Parlament/Glas Desnice ( http:// www.komentar.org.yu/, accessed 30/01/2008) or http://www.vidovdan.org/, accessed 26/04/2008. On Internet use by the German extreme right, see Fromm 2007 and Schenkel 2007.

23. Krv $i$ Čast publishes the magazines "Krv i Čast", "Novi Signal" (New Signal) and "Beli Vuk" (White Wolf). The group's newest product is "Obnova" (Renewal), whose first edition (with a focus on Kosovo) is currently advertised on the $\mathrm{Krv} i$ čast website (http://www.bhserbia.org/, accessed 28/04/2008). Srpski Sabor Dveri's magazine is called "Dveri Srpske“. The association also presents a TV programme on TV Galaksija 032 (cf. http://www.dverisrpske.com/, 15/11/2008). The first issues of the magazine "Obraz" appeared in 1995 (cf. http://www.srb-obraz.org/, Hronologija, accessed 01/03/2008).

24. Between 1999 and 2007, 31 issues of the magazine appeared. Currently, the regular issues are published electronically, while the special issues still appear in print. Cf. http:// www.stari.dverisrpske.com/, O nama, accessed 15/11/2007, see also http:// www.dverisrpske.com/, Štampano izdavaštvo and Elektronsko izdavaštvo, accessed 01/02/2008. Special issues in the past discussed, for example, "Communist crimes against the Serbian people", "Hate speech against everything Serbian" and controversial historical figures such as Draža 
Mihajlović, the World War II Četnik leader, or Nikolaj Velimirović, the early $20^{\text {th }}$ century theologian, Serbian nationalist and Orthodox saint.

25. According to Dveri, its popular Thursday lectures at Belgrade University's Technical Faculty are usually attended by several hundred people (www.staridverisrpske.com, Beogradska duhovna renesansa, accessed 15/11/2007). On other events organized by Dveri, see http:// www.dverisrpske.com/, o nama, accessed 26/04/2008.

26. Cf. http://www.stari.dverisrpske.com/, O nama, accesssed 15/11/2008, http:// www.stari.dverisrpske.com/, Aktivnosti, accessed 15/11/2008, also http:// www.dverisrpske.com/, Načela i smernice Srpskog sabora Dveri, Obnova domaćinske porodice, accessed 16/01/2008.

27. "Radi se o omladinskom pokretu za utemeljenje u crkvenom iskustvu i nacionalnom identitetu mladih ljudi koji žele da se stave na raspolaganje na korist svoje crkve i otačanstva.“ http://www.stari.dverisrpske.com/, O nama, accesssed 15/11/2008.

28. Members of Srpska Mreža include, among others, Naši (Aranđelovac, http://www.nasi.org.yu/, accessed 16/01/2008), Serbian and Bosnian chapters of the Svetosavska Omladinska Zajednica, the Sabor Omladine Justinove (Vranje), Nomokanon, and the SPC's Odbor za Jasenovac. See http:// www.vidovdan.org/, Srpska mreža, accessed 28/04/2008.

29. See Branimir Nešić, Svetosavlje i evropske integracije, http://www.dverisrpske.com/, accessed 01/02/2008, http://www.stari.dverisrpske.com/, O nama, accessed 15/11/2007, and http://www.dverisrpske.com/, Načela i smernice Srpskog Sabora Dveri, Obnova Svetosavlja, accessed 16/01/2008.

30. Byford (Jovan), «From 'Traitor' to 'Saint': Serbian Bishop Nikolaj Velimirovic in Public Memory. Analysis of Current Trends in Antisemitism series ", (ACTA), No. 22, published by the Sassoon International Centre for the Study of Antisemitism, Hebrew University, Jerusalem, 2004 ; Byford (Jovan), «Canonisation of Bishop Nikolaj Velimirović and the legitimisation of religious anti-Semitism in contemporary Serbian society ", East European Reports, 6 (3), 2004.

31. Đorđević (Mirko), Srpska konzervativna misao. Belgrade, HCHRS, 2003, p.58. The text was republished by Ihtus, a publishing company notorious for promoting right-wing extremism. Cf. http://www.dr-jurjevic.org/IhtusKatalog.pdf, accessed 27/04/2008.

32. Cf. http://www.dverisrpske.com/, Načela i smernice Srpskog Sabora Dveri, Obnova demokratije i monarhije, accessed 16/01/2008.

33. Cf. http://www.dverisrpske.com/, Načela i smernice Srpskog Sabora Dveri, Obnova parohijske zajednice i crkveno-narodnih sabora, accessed 16/01/2008: "U participativnoj demokratiji, u kojoj razna stručna i patriotska udruženja imaju svoj glas i uticaj, vidimo neophodno korekciju građanskog rata političkih stranaka koji je demolirao srpsku politiku.“ Dveri's corporativism is also expressed in their slogan "Za nacionalnu sabornost $u$ različitosti profesija!" http://www.stari.dverisrpske.com/, Aktivnosti, accessed 15/11/2007. Such ideas are resonant of ultra-conservative, clericalist regimes such as Austrofascism (cf. Tálos/Manoschek 2005).

34. Cf. http://www.dverisrpske.com/, Načela i smernice Srpskog Sabora Dveri, Obnova demokratije i monarhije, accessed 27/04/2008): "Kraljevina omogućava nadstranački red i mir (...). Kralj je simbol nacionalnog jedinstva, štit pobožnosti i čuvar državne celine."

35. "Ovo naše opredeljenje [for svetosavlje, BNW], dakle, nije mit o samozavaravanje o Srbima kao narodu najstarijem i nebeskom, već praksa svakodnevnog svedočenja duhovnih i moralnih vrednosti našeg naroda i odbrane njegovog opstanka na vekovnom životnom tlu." http:// www.dverisrpske.com/, Načela i smernice Srpskog Sabora Dveri, Obnova svetosavlja, accessed $16 / 01 / 2008$.

36. "Homoseksualizam i drugi vidovi devijantnog ponašanja, abortus ili sektaštvo za Srbe ne mogu biti normalne pojave i protiv njih ćemo se boriti svim miroljubivim sredstvima." http:// 
www.dverisrpske.com/, Načela i smernice Srpskog Sabora Dveri, Obnova srpske prosvete, accessed 16/01/2008.

37. “Obnova našeg naroda mora početi od obnove vere, duhovnosti i morala, institucija parohijske zajednice i crkveno-narodnih sabora, pa preko obnove porodice, prosvete i sela, voditi u obnovu nacije i države." http://www.dverisrpske.com/, Načela i smernice Srpskog Sabora Dveri, Uvod, accessed 16/01/2008. References to a "strong and healthy nation" can be found ibid., Obnova domaćinske porodice.

38. "Srbija se zalaže za Evropu nacija kao zajednicu različitih naroda, kao zajednicu u kojoj se susreću i kroz koju se uvažavaju razne kulture (...)." http://www.dverisrpske.com/, Načela i smernice Srpskog Sabora Dveri, Odnos sa drugima, accessed 16/01/2008.

39. "Mi ne mrzimo druge, nego volimo svoje, mi ne napadamo druge, nego branimo svoje." http://www.stari.dverisrpske.com/, O nama, accessed 15/11/2007, see also ibid., Odnos sa drugima. Specifically on anti-Semitism, see Boško Obradović, Trojanski konj antisemitizma, 01/12/2007, http://www.dverisrpske.com/, accessed 01/02/2008.

40. However, only the rights to life, property, education and equality before the law are recognized as "God-given", basic human rights. Cf. http://www.dverisrpske.com/, Načela i smernice Srpskog Sabora Dveri, Obnova srpske prosvete, accessed 16/01/2008.

41. According to Obraz, Nebojša M. Krstić founded the publishing house Srbski obraz in 1994 with the support of the SPC. The magazine "Obraz" was first published in 1995. Cf. http://www.srbobraz.org/, Hronologija, accessed 01/03/2008.

42. Cf. AI 2001.

43. Nebojša Krstić died in a car accident in 2001. His death aroused suspicions of a politically motivated murder among his admirers, who promptly proclaimed him a martyr of the national cause. Cf. Jerej Velibor Džomić, U večni spomen: Nebojša M. Krstić; Nenad M. Jovanović, Novi srpski mučenik; Bojan Mitić, Neustrašivi vitez krsta, all on http://www.srb-orbraz.org/, accessed 29/01/2008.

44. Cf. Nikolić 2001, AI 2001. Recently, Obraz again threatened to use violence in order to prevent public manifestations of gay and lesbian pride in Serbia. Cf. Homo frka, http://www.srbobraz.org/, accessed 26/04/2008.

45. This, again, is possibly due to the alleged sympathies of high-ranking individuals in Serbia's political establishmentfor Obraz and its aims.

46. Cf. http://www.obraz.org.yu/, why Obraz?, accessed 14/11/2007. This website is now defunct. The new website can be found under http://www.srb-obraz.org/.

47. "Mi smo za Srbstvo sa Obrazom i zato smo (...) za krst časni umesto demonske petokrake, za slobodu zlatu umesto novog svetskog poretka (...)." http://www.srb-obraz.org/, Osnovne smernice, accessed 01/03/2008.

48. "Obraz je jedini pokret za školu sa verom, politiku sa poštenjem, vojsku sa rodoljubljem i državu sa Božijim blagoslovom." http://www.srb-obraz.org/, o nama, accessed 01/03/2008. This phrase refers to a statement by Nikolaj Velimirović quoted ibid. See also http:// www.obraz.org.yu/, why Obraz?, accessed 14/11/2007.

49. Cf. http://www.obraz.org.yu/, The Basic Guidelines, accessed 14/11/2007, cf. also Mladen Obradović: Srbska mladost za srbsku Srbiju, http://www.srb-obraz.net/, accessed 29/01/2008.

50. Cf. http://www.obraz.org.yu/, The Basic Guidelines, accessed 14/11/2007.

51. Cf. http://www.srb-obraz.org/, Srbskim neprijateljima, accessed 01/03/2008.

52. Croats are referred to as "Ustaše", Muslims as "extremists", and Albanians as "terrorists". The term "Cionist" is defined as "anti-Christian Jewish racist". Cf. http://www.srb-obraz.org/, Srbskim neprijateljima, accessed 01/03/2008. Other "enemies" of the Serbian nation include "communists", "fascists" (sic), "satanists", “mondialists" etc. Cf. http://www.obraz.org.yu/, The Basic Principles, accessed 14/11/2007. 
53. "In our glorious Serbian history we have never and nowhere subjugated nor persecuted anyone." http://www.obraz.org.yu/, The Basic Principles, accessed 14/11/2007.

54. Cf. "God is with us!" Interview with Nenad M. Jovanović, Pravda, 01/03/2002, http:// www.newsfromrussia.com/politics/2002/03/01/26725.html, accessed 14/11/2007.

55. Cf. "Nije svaki Srbin ratni zločinac", http://www.pcnen.com/, 17/04/2002, accessed 01/02/2008; "Možda je poneki Srbin i Radovan ali nije svaki zločinac", http:// www.dnevnik.co.yu/, 18/04/2002, accessed 01/02/2008.

56. Cf. http://www.srb-obraz.org/., Srbskim neprijateljima, accessed 01/03/2008.

57. The Serbian Ministry of Interior Affairs and the Security Council of the Vojvodina Assembly classified Obraz as a clerical-fascist (klerofašistički) organization. Cf. Prvi zvaničan spisak neonacista, 10/12/2005, http://www.b92.net/ , accessed 14/11/2007.

58. Cf. http://www.obraz.org.yu/, The Basic Principles, accessed 14/11/2007.

59. Cf. http://www.bloodandhonour.com/, world Wide Chapters, accessed 02/02/2008.

60. Cf. http://www.bhserbia.org/, o nama, accessed 14/11/2007.

61. In neo-Nazi circles, "18" stands for the initials of Adolf Hitler.

62. Cf. http://www.bhserbia.org/, Osnivanje Combat 18, accessed 14/11/2007.

63. Cf. http://www.bhserbia.org/, Izdanja and Koncerti, accessed 14/11/2007.

64. Cf. http://www.bhserbia.org/, o nama, Intervju, accessed 14/11/2007. On the same website, the cowardly assault of four activists on a gay man in Belgrade in July 2004 is celebrated as a good example of "leaderless resistance". Cf. http://www.bhserbia.org/, Vesti, accessed 14/11/2007.

65. Cf. http://www.bhserbia.org/, O nama, accessed 14/11/2007. Only recently, Nacionalni stroj established its own website, cf. http://www.nacionalnistroj.org/, accessed 28/04/2008.

66. Cf. http://www.bhserbia.org/, Vesti, accessed 14/11/2007. On Goran Davidović see also his website http://www.gorandavidovic.com/. Over the past few years, Goran Davidović repeatedly came into conflict with the law. In 2006, he received a one-year prison sentence for inciting hatred after he and other members of Nacionalni stroj had attacked participants in a public discussion at the University of Novi Sad in November 2005 (cf. Osuđeni članovi Nacionalnog stroja, 10/11/2006, http://www.b92.net/, accessed 28/04/2008). The sentence will be reviewed by Serbia's High Court in June 2008 following an appeal by Davidović (cf. U junu o žalbama Nacionalnog stroja, 21/04/2008, http://www.b92.net/, accessed 28/04/2008). In connection with the Novi Sad incident, Davidović already served a seven day prison sentence for physically assaulting one of the participants (cf. Saslušanja i zatvor za neonaciste, 09/10/2007, http:// www.b92.net/, accessed 28/04/2008). In 2007, Davidović was detained and later released by the police in relation with death threats against journalist Dinko Gruhonjić published on Nacionalni stroj's pages on http://www.stormfront.org/ (cf. Goran D. pušten iz zatvora, 08/04/2007, http:// www.b92.net/, accessed 28/04/2008). In June 2007, Davidović was found guilty of libel in a law suit brought against him by Gruhonjić (cf. Odšteta za povredu časti novinara, 25/07/2007, http:// www.b92.net/, accessed 28/04/2008). In autumn 2008, Goran Davidović was interrogated by the police under suspicion of breaching public order in connection with the "March for Serbian Unity" (cf. Saslušanja i zatvor za neonaciste, 09/10/2007, http://www.b92.net/, accessed 28/04/2008).

67. Cf. http://www.b92.net/specijal/kosovo2004, accessed 04/02/2008.

68. Cf. http://www.bhserbia.org/, Vesti, accessed 02/02/2008.

69. Cf. Ipak zabranjen skup neonacista, 26/09/2007 and Incident na antifašističkom skupu, 07/10/2008, both on http://www.b92.net/, accessed 27/04/2008. For Krv $i$ čast's version of the event, cf. http://www.bhserbia.org/, Vesti, accessed 02/02/2008. For Nacionalni Stroj's version, cf. Goran Davidović: O događajima 7. oktobra u Novom Sadu, http://www.gorandavidovic.com/, Tekstovi, accessed 02/02/2008.

70. Cf. http://www.stormfront.org/, Stormfront Srbija, Aktivizam, accessed 02/02/2008.

71. Examples can be viewed on http://www.stormfront.org/, Aktivizam, accessed 28/04/2008. 
72. Cf. http://www.bhserbia.org/, Deset Principa Nacional Socijalizma and Lična Revolucija, accessed 14/11/2007.

73. Cf. http://www.bhserbia.org/, Biblioteka, Članci, Abortus, sredstvo planskog uništenja and Muškarci i žene, accessed 14/11/2007.

74. Cf. http://www.bhserbia.org/, Osnivanje Combat 18 u Srbiji, accessed 14/11/2007. The website hosts the notorious antisemitic pamphlet "Protocols of the Elders of Zion" (http:// www.bhserbia.org/, Biblioteka, Knjige, accessed 02/02/2008). Copies of anti-Semitic publications such as Milorad Mojić' "Srpski narod u kandžama Jevreja" (The Serbian people in the claws of the Jews", ca. 1941) and Vasa Pelagić' "Vjerozakonsko učenje Talmuda" (The Talmudic Teachings of Religious Law, 1877) can be bought from Krv i čast, cf. http://www.bhserbia.org/, Izdanja, Brošure, accessed 02/02/2008.

75. "Samo su ljudi snažne ličnosti i volje spremni da žrtvuju sve i krenu u borbu za spasenje i preporod naše nacije i rase i rušenje cionističko-kapitalističkog sistema koji uništava našu voljenu majku Srbiju." http://www.bhserbia.org/, Biblioteka, Članci, Lična revolucija, accessed $14 / 11 / 2007$.

76. http://www.bhserbia.org/, Glavna, accessed 02/02/2008: “24. mart 1999 - 24. mart 2007: Osam godina od cionističke NATO agresije na Srbiju." On March 24, 2007, Nacionalni stroj organized a public meeting in Belgrade to mark the eighth anniversary of the beginning of the NATO bombardement. Among the speakers was Goran Davidović. Cf. http:// www.stormfront.org/, Aktivizam, Memorialni skup, accessed 13/11/2007. A similar meeting this year was banned by the authorities, but took place nevertheless. Cf. http:// www.nacionalnistroj.org/, accessed 30/04/2008.

77. Obraz refers to NATO as "Judeo-masonic murderers", http://www.obraz.org.yu/, The Basic Principles, accessed 14/11/2007.

78. Cf. http://www.bhserbia.org/, O nama, Intervju, accessed 14/11/2007. This is another parallel between Krv i čast and Obraz.

79. Cf. http://www.stormfront.org/, Nacionalni Stroj, Aktivizam, Program i statut Nacionalnog Stroja, accessed 13/11/2007: "Cilj Nacionalnog stroja je očuvanje i preporod zdravih vrednosti srpske nacije, kao sastavnog dela bele rase (...)."

80. Cf. http://www.stormfront.org/, Nacionalni Stroj, Aktivizam, Program i statut Nacionalnog Stroja, accessed 13/11/2007. Quotations: "Zalagaćemo se za unitarnu srpsku nacionalnu državu u kojoj će osnovna načela biti nacionalna sloboda, socijalna pravda i rasno biološka zaštita naroda.“ (pt. 5); "U korist jedinstvene funkcije srpskog nacionalnog tela, rasna i nacionalna svest mora ugasiti borbu među klasama i strukama $u$ jedinstvu, od radnika i seljaka do intelektualaca, da svako vrši svoju funkciju u organskoj narodnoj zajednici.“ (pt. 26) Again, the similarity to Obraz's programme is striking, the one main difference being Nacionalni stroj's emphasis on racism.

\section{ABSTRACTS}

This paper surveyed the extreme right scene in contemporary Serbia and discussed four groups Srpski Sabor Dveri, Otačastveni Pokret Obraz, Krv i čast and Nacionalni stroj - in more detail. It showed that the programmes of these organizations are strikingly similar in that they focus on an exaggerated nationalism centred on the idea of national rebirth and a populist suspicion of democratic values, institutions and processes. The main difference seems to be that the Christian right groups yearn for a renewal of the nation through a return to "traditional values", among 
which Orthodox piety, hierarchical social relations and a rural way of life feature most prominently, while the racist right associations strive for a national renaissance based on the alleged supremacy of the white "race".

Cet article étudie l'extrême droite dans la Serbie d'aujourd'hui et aborde quatre groupes - Srpski Sabor Dveri, Otačastveni Pokret Obraz, Krv i čast et Nacionalni stroj -plus en détails. Il montre que les programmes de ces organisations sont très semblables en ce qu'ils se concentrent sur un nationalisme exacerbé basé sur l'idée de la renaissance nationale et une remise en cause populiste des valeurs, des institutions et des processus démocratiques. La principale différence semble être que les groupes de la droite chrétienne aspirent à un renouveau de la nation par un retour aux "valeurs traditionnelles", dont la piété orthodoxe, les relations sociales hiérarchiques et un mode de vie rurale prédominant, tandis que les associations de la droite raciste œuvrent en faveur d'une renaissance nationale fondée sur la prétendue suprématie de la "race" blanche.

\section{INDEX}

Geographical index: Serbie

Mots-clés: Extrême droite, Nationalisme

\section{AUTHOR}

BARBARA N. WIESINGER

PhD (University of Salzburg, Austria), historianbarbarawiesinger@hotmail.com 